\title{
AS ESPÉCIES DE EUGLOSSA LATREILLE DO NORDESTE DE SÃO PAULO (APIDAE, EUGLOSSINAE) ${ }^{1}$
}

\author{
José Manuel Macário Rebêlo ${ }^{2}$ \\ Jesus S. Moure ${ }^{3}$
}

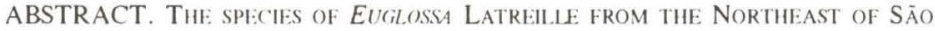
Pallo. Brazil. (APII)AE. ElgilossinaE). A key and short descriptions are given to the males of the eleven species of Euglossa Latreille, 1802. collected in cineole. eugenol and vanillin in natural forest reserves of the Northeast of São Paulo State (Cajuru. Sertãozinho, Dumont, Ribeirão Preto, Luís Antônio and Pedregulho). Namely: E. imperialis Cockerell. 1922: E. annectans Dressler. 1982: E. pleosticta Dressler, 1982: E. townsendi Cockerell, 1904: E. melanotricha Moure, 1967: E. cordata (Linacus, 1758): E. securigera Dressler, 1982: E. fimbriata, sp.n.: $E$. leucotricha, sp.n.: E. truncala, sp.n. and E. violaceifrons, sp.n..

KEY WORDS. Apidae. Euglossini. Euglossa. Glossura. Cineol. Eugenol. Vanilin. Systematics
\end{abstract}

Durante algum tempo o estudo taxonômico dos Euglossini foi baseado principalmente em caracteres das fêmeas (MOURE 1967). Mas, nas duas últimas décadas, devido ao uso intensivo de íscas químicas na atração de machos, estes passaram a ser mais coletados e utilizados para levantamentos faunísticos e estudos de biodiversidade e o número de espécies descritas aumentou quase 50\% (KYMSEY \& DRESSLER 1986).

Este trahalho haseia-se no estudo dos machos.

Foram obtidas 11 espécies de Euglossa Latreille, 1802, das quais quatro novas, em iscas de cineol, eugenol e vanilina nas reservas de florestas naturais do Nordeste do Estado de São Paulo situadas em Cajuru (REbÊlo \& Garófalo 1991), Sertãozinho, Pedregulho (Mateus et al. 1993), Dumont, Ribeirão Preto e Luís Antônio. Os exemplares estudados estão depositados na Coleção Camargo, Museu da USP, em Ribeirão Preto, São Paulo (FFCLRP-USP) e na Coleção de Entomologia Pe. Jesus S. Moure, Departamento de Zoologia da Universidade Federal do Paraná (DZUP).

1) Contribuição número 877 do Departamento de Zoologia, Universidade Federal do Paraná.

2) Departamento de Patologia. Universidaade Federal do Maranhão. Praça Madre de Deus, 02. 65025-560 São Luis, Maranhão, Brasil.

3) Departamento de Zoologia. Universidade Federal do Paraná. Caixa Postal 19020, 81531-990 Curitiba. Paraná. Brasil. Bolsista do CNPq. 


\section{CARACTERES}

Os caracteres selecionados para a construção da chave e das descrições se baseiam em quatro ítens principais: A) colorido do tegumento (itens 1-3), B) comprimento e côr da pilosidade (itens 4-6), C) pontuação do tegumento (itens 7-8) e D) formato de determinadas estruturas (itens 9-16), algumas delas relacionadas com a coleta de óleos aromáticos.

(1) Cor do tegumento. Apesar de alguns inconvenientes, a côr do corpo é taxonomicamente importante. Varia de verde-claro a -dourado, até cúpreo e ígneo por um lado, ou para o verde-azulado, azul e violeta por outro, podendo chegar a verde-brônzeo, ou escuro. Nos exemplares em estudo não ocorrem variações contrastantes entre diferentes partes do corpo, como em E. mixta Friese, 1899.

(2) Cor do clípeo. Destaca-se o disco do clípeo entre as fortes carenas em ogiva, das áreas laterais em declive, pelo colorido, de verde a verde-azul, azul-cinza, azul e violeta, sendo as áreas laterais em geral verde-douradas. A cor da fronte pode acompanhar a do clípeo ou ser dourada ou contrastada em violeta.

(3) Manchas e estrias branco-marfim. a) Mancha no escapo: pode recobrir parte ou toda superfície anterior do escapo, ou faltar em algumas espécies. b) Estria da área parocular inferior: pode ser completa, quando alcança o canto látero-ventral do clípeo, alargada ou não inferiormente, incompleta ou nula em algumas espécies. c) Mancha na área malar: pode recobrir inteiramente (maioria dos casos) ou apenas uma porção da área malar (Fig. 1A).

(4) Pilosidade dos mesepisternos e metepisternos. Pode ser de colorido uniforme pálido ou ter pêlos pretos intercalados no terço superior. É de particular importância o colorido dos pêlos que formam um "tufo" na porção superior dos metepisternos. Embora possa apresentar alguma variação este carater serve para separar algumas espécies.

(5) Franjas pós-glandulares. Na metade inferior do bordo posterior das tíbias metatorácicas. Podem estas estar formadas por cerdas esparsas e curtas $(0,43-0,50 \mathrm{~mm})$, densas e médias $(0,60-0,65 \mathrm{~mm})$, ou densas e longas $(0,70$ $1 \mathrm{~mm})$. O contorno formado pela franja é uniformemente convexo, ou mais atenuado para o ápice que para a base (Fig. 1C-11).

(6) Comprimento dos pêlos dos tufos laterais do quinto tergo. Variam desde curtos e esparsos até longos e densos.

(7) Pontuação do mesoscuto. Pode ser esparsa (espaço entre os pontos maior que o diâmetro do ponto = dp), relativamente densa ou moderada (espaço entre os pontos igual ao dp), densa (espaço entre os pontos menor que o dp. mas sem ser carenado) até densíssima (espaço entre os pontos careniforme, menor que o dp). Pelo tamanho dos pontos pode ser fina (dp menor que $0,03 \mathrm{~mm}$ ), moderada (dp entre 0,03 e $0,04 \mathrm{~mm}$ ) e grossa (dp maior que $0,04 \mathrm{~mm}$ ). Podem ocorrer simultaneamente pontos de dois tamanhos.

(8) Pontuação do quinto tergo. Particularmente útil pelo contraste com a dos demais tergos pela densidade, forma e tamanho dos pontos; presença ou não de uma linha média lisa longitudinal. 


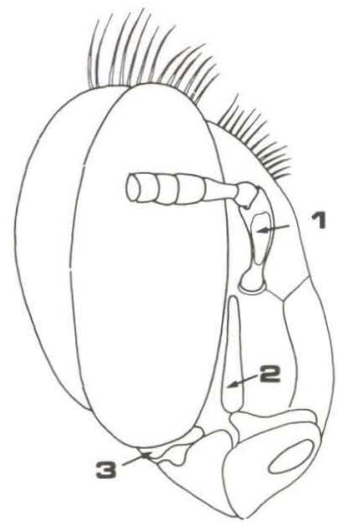

(A)

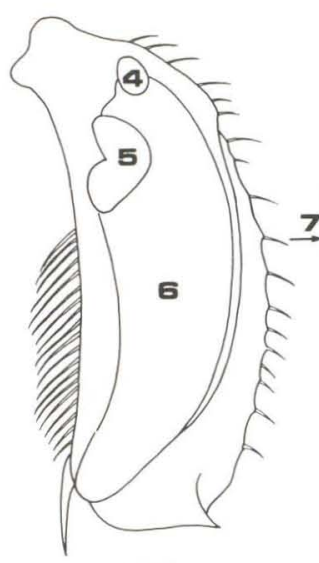

(B)

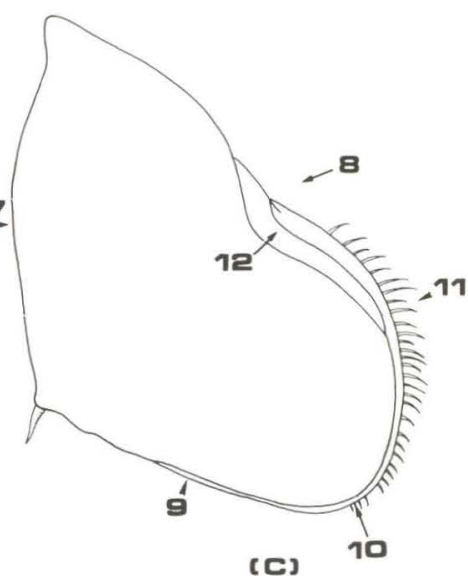

(C)

Fig. 1. (A) Cabeça do macho, de perfil, com indicação das manchas branco-marfim no escapo (1), da estria parocular inferior (2), da mancha malar (3); (B) face externa da tíbia esquerda do segundo par, com indicação dos coxins basal (4) e anterior (5), e da área aveludada (6); (C) tíbia posterior esquerda com indicação dos bordos anterior (7), posterior (8) e distal (9), do canto distal posterior (10), da franja pós-glandular (11) e da depressão posterior (12).

(9) Porção pós-palpal da gálea. Observada em repouso ao longo do corpo: diz-se curta quando chega ao segundo ou terceiro esternos metasomáticos, e longa, se alcança ou sobrepassa o ápice do abdômen. As vezes é difícil essa comparação, pelo enrolamento da gálea, ou seu posicionamento anormal.

(10) Escutelo. O formato é distintivo em algumas espécies pela presença ou não de uma depressão ao longo da linha média, dando-lhe um aspecto bigiboso quando muito pronunciada, ou uniformemente convexo quando falta; o contorno posterior pode ser arqueado ou truncado. Seu comprimento na linha média é comparado ao da largura.

(11) Área aveludada da face externa da tíbia mesotorácica. Seu comprimento e largura são de valor na separação de algumas espécies; considera-se completa quando alcança o bordo ântero-distal da tíbia (Fig. 1B).

(12) Coxins de pêlos diferenciados na base da área aveludada da tíbia mesotorácica. Geralmente são dois: o basal e o anterior. O basal bastante menor, situado póstero-superiormente. Nas espécies aquí analisadas, varia entre circular e elipsóide, podendo faltar, como em E. imperialis. Mais ou menos próximo fica o anterior, que assume contornos muito variados principalmente pelo recorte do bordo anterior, desde nulo até profundamente chanfrado. Mostrou-se fundamental na caracterização das espécies (Fig. 1B).

(13) Tíbia metatorácica. Apesar de bastante difícil a definição do seu contorno, é importante no reconhecimento de grupos de espécies. Pode ser oblonga e rombóide (quando o bordo anterior convexo é curto, cerca da metade do comprimento do bordo posterior, este biconvexo com a metade distal mais pronunciadamente e o canto distal posterior obtuso ou rombudo); subtriangular, e rombóide (com o bordo anterior convexo, um pouco mais de dois 
terços do posterior; este convexo ou hiconvexo e o canto distal posterior em ângulo sub-agudo ou reto e o vértice rombudo); triangular (com o bordo anterior ligeiramente convexo, o posterior quase reto e o canto distal posterior projetado em ângulo agudo de vértice arredondado)(Fig. IC).

(14) Depressão posterior da tíbia metatorácica. Apresenta-se como um sulco ao longo do bordo posterior e contém a abertura de entrada do órgão tíbial; sua dimensão é útil na distinção de algumas espécies (Fig. 1C). Pode estar continuada até a extremidade do canto póstero-distal, ou mesmo avançar ao longo do bordo distal.

(15) Depressão marginal dos tergos. Varia na largura e pode ser lisa ou rugosa.

(16) Segundo esterno. Pode estar todo coberto por pilosidade ou apenas na porção média; ou a pilosidade ladeando uma forte depressão em fenda a cada lado, formando duas bolsas basais distantes entre si ou próximas e convergentes para trás ao longo da linha média; em alguns grupos essas bolsas são rasas e os bordos da depressão contornados por cerdas curtas; em outras espécies não há bolsas, mas apenas pequenos tufos pilosos afastados do meio. Mesmo estes podem faltar por completo. O bordo distal do esterno pode ser amplamente bissinuado com o tufo piloso antes de cada emarginação, ou simplesmente arqueado (Fig. 8).

\section{Chave para as espécies de Euglossa do Nordeste de São Paulo}

1. Porção pós-palpal da gálea longa, em repouso alcança ou sobrepassa o ápice do abdômen; escutelo higiboso, fortemente deprimido ao longo da linha média; coxim anterior subtriangular, com o bordo anterior contínuo, ou oval (Figs 4A, B); hasitarsos mesotorácicos com uma quilha na face inferior; tíbia posterior oblongo-triangular. . . . . . . . . . . . (Glossura) . 2

- Porção pós-palpal da gálea curta alcançando no máximo a margem do terceiro esterno metasomal; escutelo levemente giboso, ou apenas com leve depressão longitudinal na metade ou no terço distal do eixo médio; coxim anterior com seu bordo externo chanfrado até profundamente hilobado (Figs 4C,D,E; 5F-K); basitarsos mesotorácicos sem quilha na porção ânterobasal da face interna; tíbia posterior nunca subtriangular . (Euglossa) . 3

2. Escapo com estria branco-marfim nos dois terços da face anterior; área malar toda branco-marfim (Fig. 2A); disco do clípeo verde; coxim basal ausente. o anterior triangular (Fig. 4A) depressão posterior curta, sem alcançar o ápice da tíbia (Fig. 6A); segundo esterno com duas fendas pilosas convergentes na linha média, o bordo apical arqueado (Fig. 8A) . . . imperialis

- Escapo com a face anterior inteiramente branco-marfim (Fig. 2B) área malar com a mancha branco-marfim reduzida à porção anterior; disco do clípeo de cor violácea; coxim basal arredondado, distante do anterior, este maior, oval (Fig. 4B); depressão posterior longa (Fig. 6B), alcançando o ápice da tíbia; segundo esterno sem fendas pilosas, com o bordo apical bissinuado, e um tufo piloso antes de cada emarginação (Fig. 8B) . . . . . anmectans 
3. Coxim anterior levemente emarginado, subtriangular (Figs 4C-E); tíbia metatorácica oblongo-rombóide (Figs $6 \mathrm{C}-\mathrm{E}) \ldots \ldots \ldots \ldots \ldots$

- Coxim anterior profundamente emarginado, de várias formas (Fig. 5F-K); tíbia metatorácica sub-trapezóide a sub-rombóide $(\mathrm{Fig} .7 \mathrm{~F}-\mathrm{K}) \ldots \ldots . \ldots 6$

4. Bordo posterior do escutelo truncado; coxim anterior levemente emarginado no meio (Fig. 4C); disco do clípeo violáceo; escapo todo preto; clípeo, área supraclipeal e fronte com alguns pêlos pretos misturados aos fulvo-claros; tufo dos metepisternos predominantemente preto; pêlos da franja pósglandular (Fig. 6C) tão longos ou mais longos que o comprimento do pedicelo e primeiro flagelomero juntos . . . . . . . . . . truncata

- Bordo posterior do escutelo convexo; coxim anterior emarginado em cunha ou formando um lobo inferior arredondado; disco do clípeo azul ou violeta nas carenas; escapo com estria hranco-martim; clípeo, áreas paroculares e fronte apenas com pêlos fulvo-claros; tufo do metepisterno fulvo-claro (às vezes com alguns pêlos pretos misturados): pêlos da franja pós-glandular mais curtos que o comprimento do pedicelo e primeiro flagelômero juntos.

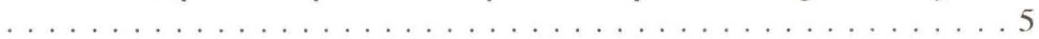

5. Escutelo com leve depressão média longitudinal; coxim anterior com uma reentrância cuneiforme formando dois lobos subiguais; coxim basal oblongo (Fig. 4D); tîhia metatorácica bastante intumescida, com forte brilho dourado $($ Fig. 6D) . . . . . . . . . . . . . . . . pleosticta

- Escutelo sem depressão média; coxim anterior emarginado no terço distal formando um pequeno lobo arredondado; coxim basal arredondado (Fig. 4E); tîhia metatorácica um pouco deprimida distalmente, verde, sem brilho dourado (Fig. 6E) . . . . . . . . . . . . . . . . townsendi

6. Tegumento verde-azulado pelo menos no mesoscuto e escutelo; escapo inteiramente preto; mesepisternos com pêlos brancos e pretos misturados; pontuação do mesoscuto e escutelo densíssima (intervalos entre os pontos sub-careniformes) . . . . . . . . . . . . . . . . . 7

- Tegumento verde-dourado; escapo com ou sem estria branco-marfim; pêlos do mesepisterno brancos ou fulvo-claros; pontuação do mesoscuto e escutelo relativamente densa (intervalos entre os pontos não carenados) . . . . . 8

7. Pêlos do bordo posterior das tibias e dos fêmures protorácicos predominantemente pretos; os das franjas laterais do quinto tergo e do bordo pósglandular muito mais longos que a distância ocelorbital (Fig. 7F); coxim anterior reniforme (Fig. 5F); depressão marginal do terceiro ao quinto tergo, rugosa; pontuação do quinto tergo superficial, esparsa e irregular . $\ldots \ldots \ldots \ldots \ldots \ldots$ melanorricha

- Pêlos do bordo posterior das tíbias e dos fêmures protorácicos brancos; os das franjas laterais do quinto tergo e do bordo pós-glandular tão longos quanto a distância ocelorbital(Fig. 6G); coxim anterior estreito e arqueado (Fig. $5 \mathrm{G})$; depressão marģinal do terceiro ao quinto tergo, lisa: pontuação do 
quinto tergo densíssima (intervalos entre os pontos carenados) com pontos fortes e regulares . . . . . . . . . . . . . . . . leucotricha

8. Estrias paroculares inferiores estendendo-se até os cantos látero-ventrais do clípeo (Fig. 3H); área aveludada sem chegar ao bordo distal da tíbia mesotorácica; coxim anterior em forma de L, emarginado em ângulo reto, deixando o lobo interior semi-arredondado e o superior alongado (Fig. 5H); tíbia metatorácica inchada, verde dourada, com ápice obtuso (Fig. 7H) . .

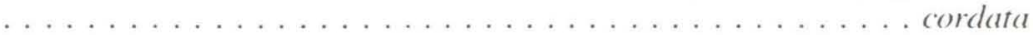

- Estrias paroculares inferiores incompletas, sem chegar aos cantos látero-ventrais do clípeo (Fig. 3I.J), ou chegando (Fig. 3K): área aveludada completa (Fig. $5 \mathrm{I}, \mathrm{K})$; coxim anterior com reentrância cuneiforme deixando o lobo inferior semi-arredondado e o superior alongado (Fig. 5J,K), ou profundamente emarginado formando dois lobos subparalelos (Fig. 5I); tíbia metatorácica gradualmente deprimida para a margem distal, de cor verde-escura ou azulada com ápice subagudo ou em ângulo reto . . . . . . . . . . . . . 9

9. Disco do clípeo verde, um pouco mais escuro que suas áreas laterais; pontuação da metade distal da tíhia metatorácica grosisa e densa; esta sem rehordo pré-apical e com ápice levemente levantado (Fig. 71); hordo posterior do escutelo truncado; coxim anterior profundamente emarginado formando dois lobos subparalelos (Fig. 5I) . . . . . . . . . . . securigera

- Disco do clípeo verde-azulado ou violeta, contrastando com suas áreas laterais verde-douradas; pontuação da metade distal da tíhia metatorácica grossa e bastante esparsa; esta com rebordo pré-apical e com ápice subagudo projetado para trás; bordo posterior do escutelo arqueado: coxim anterior com uma reentrância cuneiforme deixando o lobo inferior semiarredondado e o superior alongado ou subiguais (Fig. 5J,K) . . . . . . . . . . 10

10. Pontuação do quinto tergo grossa, densíssima, sem área lisa na linha média longitudinal; os pêlos maiores da franja pós-glandular (Fig̨. 7J) iguais ou mais longos que o pedicelo e os dois primeiros flagelomeros juntos (Fig. 3J); escutelo com leve depressão média, a pontuação quase tão densa quanto a do mesoscuto . . . . . . . . . . . . . . . . . fimbriata

- Pontuação do quinto tergo grossa porém, esparsa e irregular, deixando uma área lisa na linha média longitudinal; os pêlos maiores da franja pós-g̨landular (Fig. 7K) mais curtos que o pedicelo e os dois primeiros flagelômeros juntos (Fig. 3K); escutelo sem depressão média e com pontuação mais esparsa que a do mesoscuto . . . . . . . . . . . . . . . . violaceifions

\section{Euglossa (Glossura) Cockerell, 1917}

Este subgênero inclui as espécies caracterizadas pela gálea. língua e paraglosias muito longas, estendendo-se pelo menos até o ápice do ahdômen quando em repouso, e pelo escutelo fortemente higiboso. Mandíbulas do macho bidentadas. Moure (1969) considerou o labro mais longo que largo e a presença 

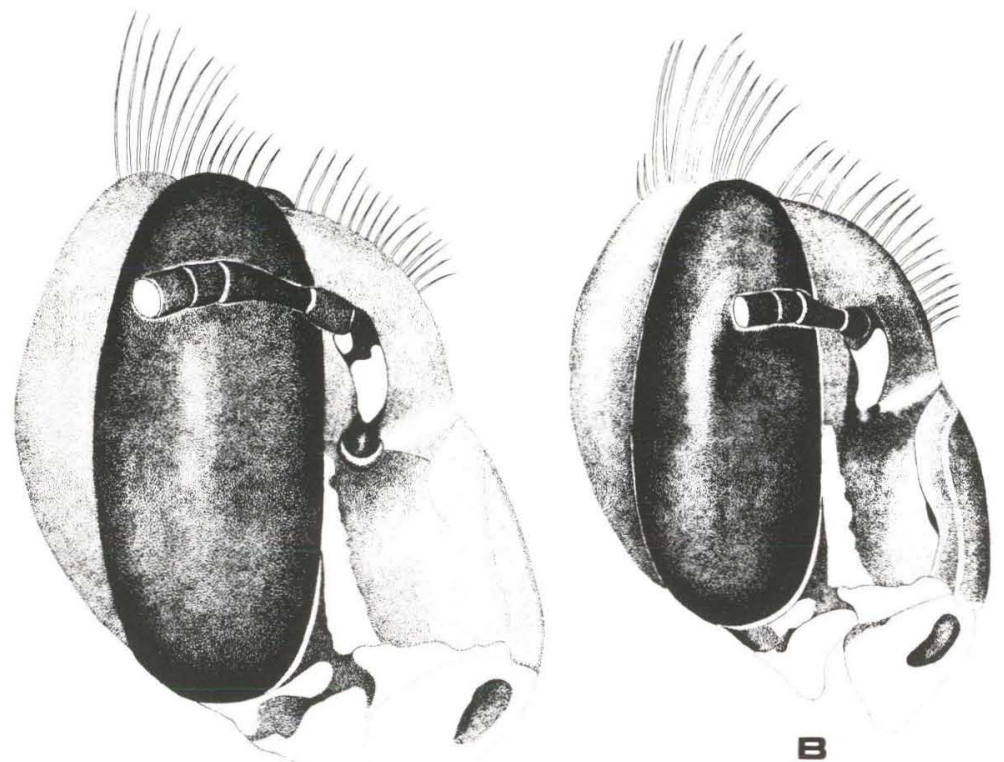

$\mathbf{A}$
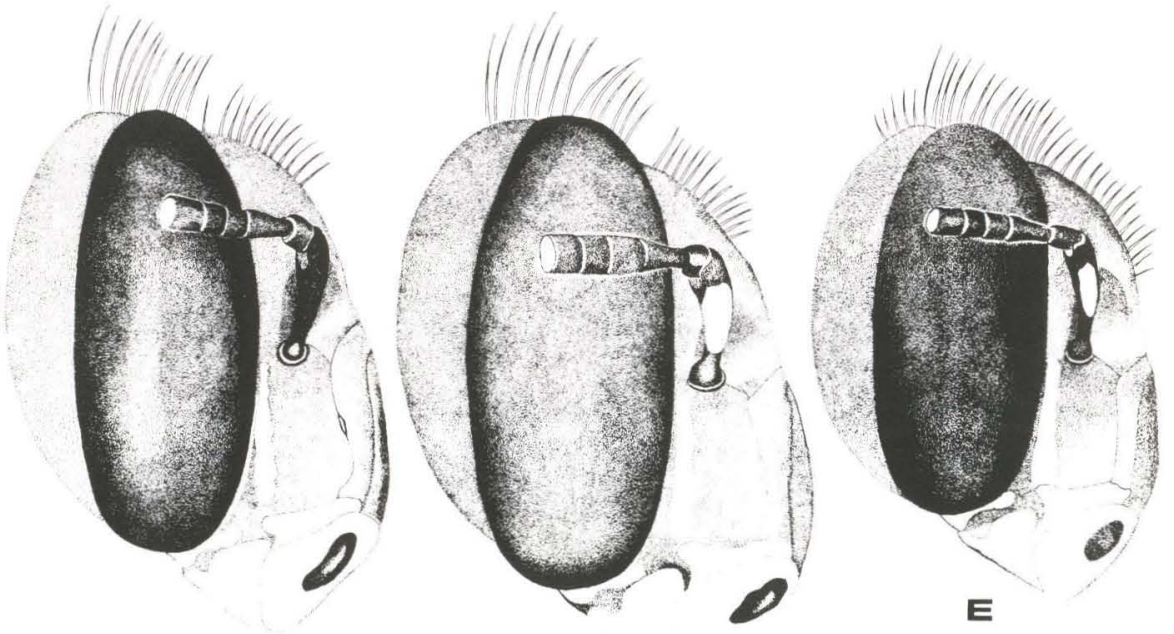

$\mathbf{C}$

Fig. 2. Cabeça do macho, vista de perfil com destaque para a protuberância do clípeo e das manchas branco-marfim no escapo, estria parocular inferior e mancha malar. (A) Euglossa imperialis; (B) E. annectens; (C) E. truncata; (D) E. pleosticta; (E) E. townsendi. 
de uma quina na superfície ântero-inferior dos hasitarsos mesotorácicos como autapomorfias. DRESSLER (1978h), entretanto, interpretou estes atributos e o escutelo higiboso como caracteres associados ao grande porte das abelhas e acrescentou, como próprios do grupo: coxim anterior inteiro, ângulo do pronoto obtuso e tíhia metatorácica triangular. Duas espécies deste subgênero ocorrem na região em estudo.

\section{Euglossa (Glossura) imperialis Cockerell, 1922}

\section{Figs 2A, 4A, 6A, 8A}

(1) Tegumento verde-azulado na cabeça, mesoscuto e escutelo; (2) diseo do clípeo verde, com carena média dourada ou brônzea; (3a) estria do escapo ocupando de um a dois terços da face anterior (Fig. 2A); (3b) manchas nas áreas paroculares inferiores completas, alargadas embaixo (Fig. 2A); (3c) áreas malares inteiramente brancas (Fig. 2A). (4) Pêlos no tufo dos metepisternos fulvo-claros e pretos misturados; (5) nas franjas pós-glandulares longos, até $1 \mathrm{~mm}$ (Fig. 6A); (6) sem formar tufos laterais no quinto tergo. (7) Pontuação no disco posterior do mesoscuto esparsa e com pontos de diferentes tamanhos $(0,03-0,05 \mathrm{~mm})$, (8) densíssima no quinto terģo com pontos regulares $(0,06 \mathrm{~mm})$. (9) Porção pós-palpal da gálea longa, sobrepassando o ápice do abdômen. (10) Escutelo bigiboso, com uma forte depressão média, arredondado nos lados e sinuado no meio do bordo posterior. (11) Área aveludada das tíhias médias estreita, encurtada distalmente. (12) Coxim anterior de aspecto triangular, com uma leve reentrância no primeiro terço do bordo anterior (Fig. 4A). (13) Tíbia metatorácica triangular com o canto posterior em ângulo subagudo de ápice rombudo, mas bastante projetado para trás (Fig. 6A); (14) depressão glandular um pouco mais de 1/3 do bordo posterior da tíbia (Fig. 6A). (15) Depressão marginal dos tergos III, IV e V larga, respectivamente 0,20: 0,18:0,12 mm. (16) Esterno II com duas fendas pilosas convergentes para a linha média; o bordo posterior contínuo, sem emarginações laterais (Fig. $8 \mathrm{~A})$.

Holótipo fêmea. USNM $n^{\circ} 24822$, encontra-se no National Museum of Natural History, Smithsonian Institution. Foi estudado por MoURE (1957). Localidade típo: Rio Trinidad, Panamá.

Material examinado. BrasıL, Sào Paulo: Pedregulho (Reserva Ecológica de Pedregulho), 23-XII-1989, 06-I/04-II/24-25-V-1990, S. Mateus leg. (10 machos). Foram vistos numerosos exemplares da Amazônia e Mata Atlântica para comparação.

Distribuição geográfica. É uma espécie tipicamente Amazônica, entrando profundamente na Mata Atlântica até o Espírito Santo, mas agora, curiosamente com registros no Oeste de Minas Gerais e Norte de São Paulo. Em Pedregulho, extremo Norte de São Paulo, os machos são atraídos pelo cineol. Porém, mais para o sul (Cajuru e Luís Antônio), pouquíssimos indivíduos visitam esta ísca. Não existem registros indicando continuidade destas populações com as da bacia Amazônica através do Brasil Central, possivelmente por falta de coletas. Mas, apesar disso, essas populações praticamente não diferem entre si. 


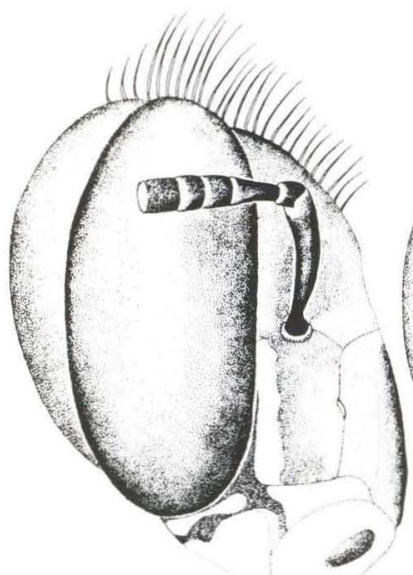

$\mathbf{F}$

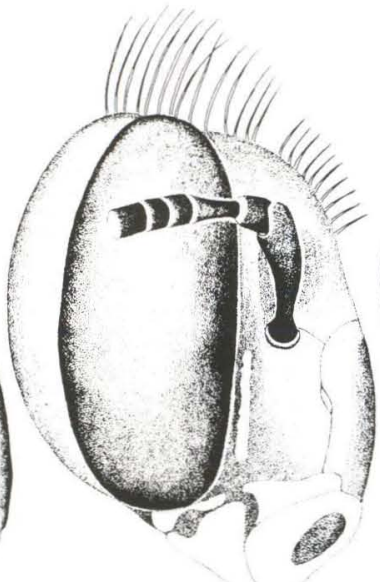

G

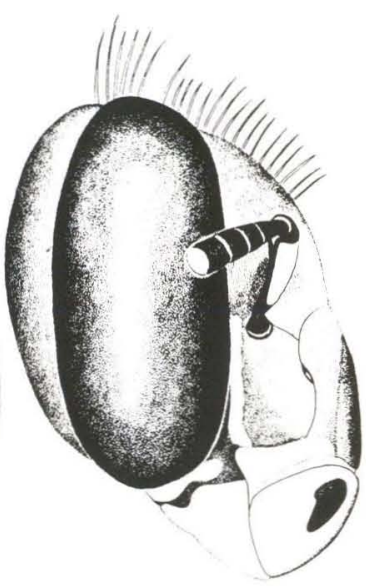

$\mathbf{H}$

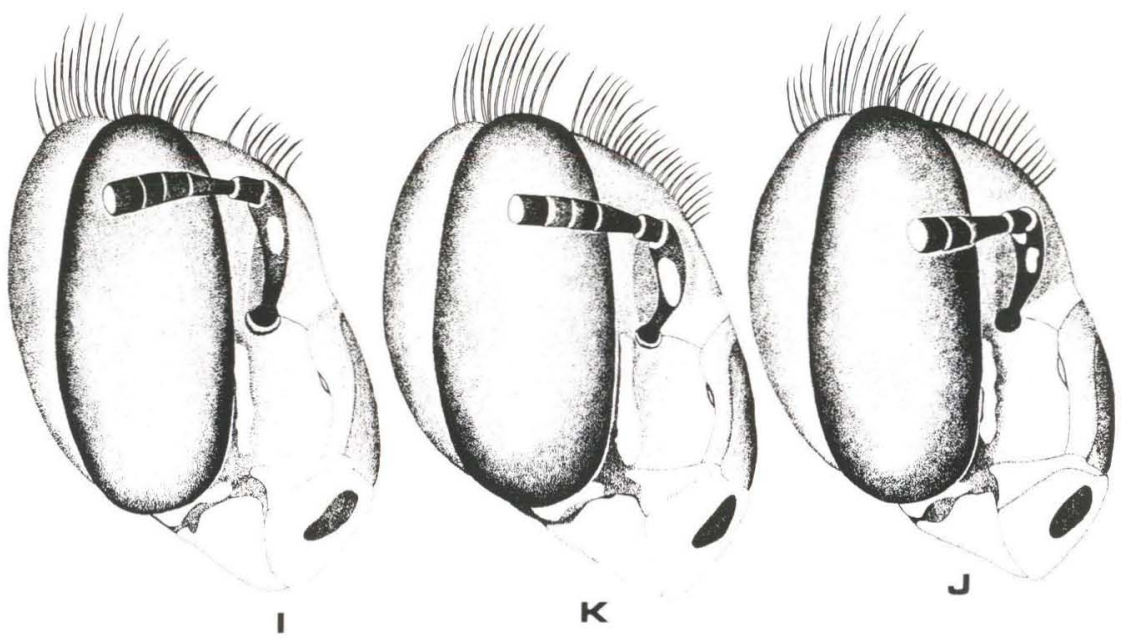

Fig. 3. Cabeça do macho, vista de perfil com destaque para a protuberância do clípeo e das manchas branco-marfim no escapo, estria parocular inferior e mancha malar. (F) Euglossa melanotricha; (G) E. leucotricha; (H) E. cordata; (I) E. securigera; (J) E. fimbriata; (K) E. violaceifrons.

Comentários. Forma com piliventris Guérin, 1845, chalybeata Friese, 1925, ignita Smith, 1874, e flammea Moure, 1969, um grupo natural: todas têm a glossa extremamente longa. As três primeiras são abundantes nas matas úmidas da Amazônia,além disso chalybeata e ignita são comuns na Mata Atlântica e a quarta ocorre em Costa Rica. Euglossa imperialis separa-se das outras espécies deste grupo pelo coxim anterior inteiro tendo apenas uma pequena chanfradura no bordo anterior. Outras diferenças estruturais estão descritas em MOURE (1969).

Separa-se facilmente das demais espécies do Nordeste de São Paulo pelo 

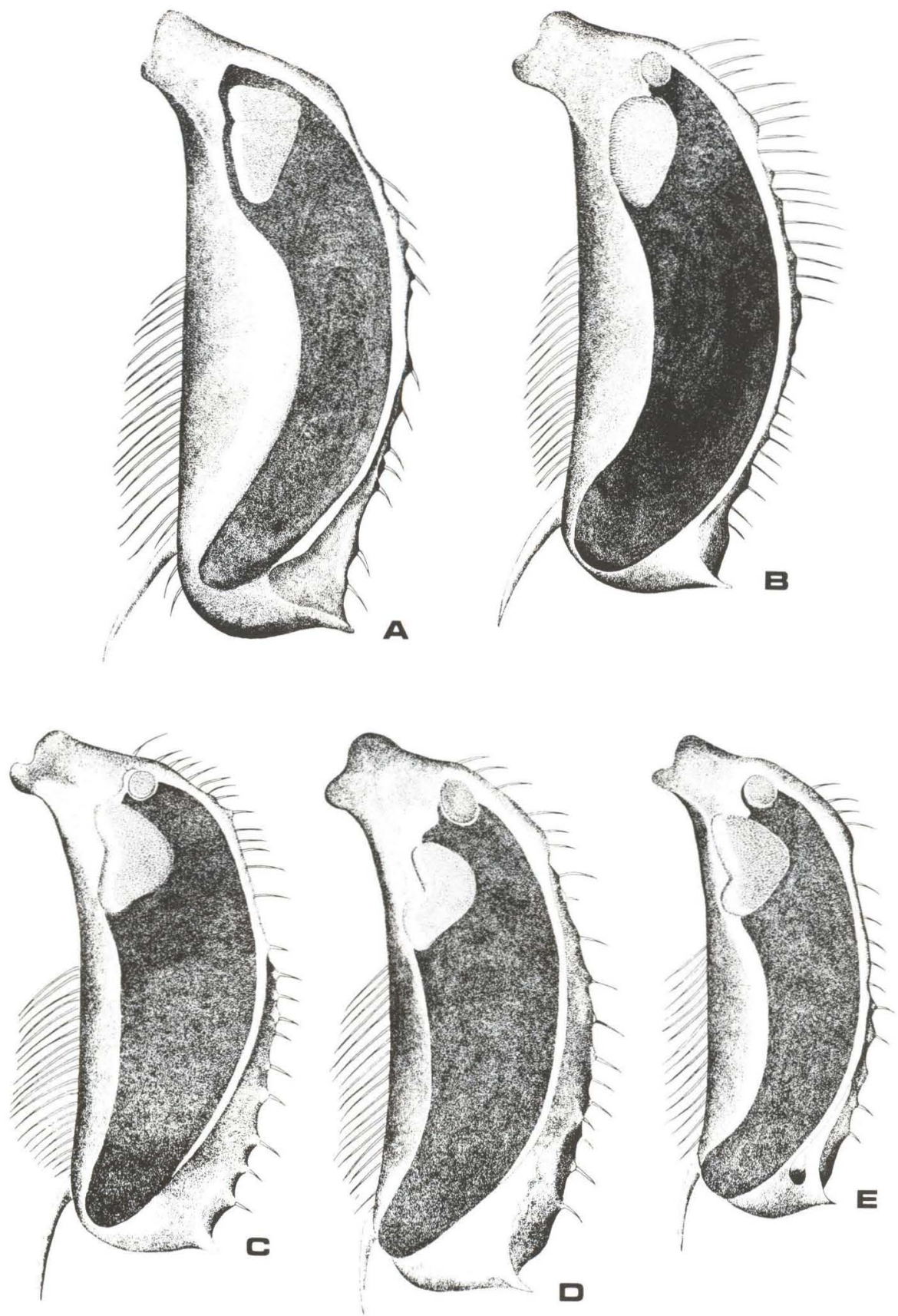

Fig. 4. Vista lateral da mesotíbia esquerda com destaque para a área aveludada e coxins. (A) Euglossa imperialis; (B) E. annectens; (C) E. truncata; (D) E. pleosticta; (E) E. townsendi. 
porte avantajado do corpo, peças bucais muito mais longas que o corpo, sobressaindo ao ápice do abdômen, fato que inspirou o nome subgenérico dado a este grupo; pelo segundo esterno, no disco, com duas grandes fendas pilosas convergentes apicalmente para a linha média.

\section{Euglossa (Glossura) annectans Dressler, 1982}

Figs $2 B, 4 B, 6 B, 8 B$

Os caracteres 3h, 4, 5, 10 como em imperialis. (1) Tegumento geral verde-azulado. (2) Disco do clípeo azul intenso a violeta, contrastando com suas áreas laterais verde-claras. (3a) Face anterior do escapo inteiramente brancomartiom (Fig. 2B). (3c) Manchas das áreas malares reduzidas à porção anterior (Fig. 2B). (4) Tufo dos metepisternos com pêlos fulvo-claros. (6) Nos tufos laterais do quinto tergo os pêlos esparsos e curtos, 0,26 mm. (7) Pontuação do disco posterior do mesoscuto esparsa e fina $(0,03 \mathrm{~mm})$, (8) no tergo $\mathrm{V}$ densíssima, com pontos regulares, hexagonais $(0,05-0,06 \mathrm{~mm})$. (9) Porção pós-palpal da gálea, longa, alcançando o ápice do abdômen. (11) Área aveludada da tíbia mesotorácica completa (Fig. 4B). (12) Coxim basal pequeno, circular; o anterior oval sem reentrância (Fig. 4B). (13) Tíbias metatorácicas triangulares (Fig. 6B); (14) depressão glandular longa chegando, praticamente, ao ângulo apical da tíhia (cerca de dois terços do bordo posterior da tíbia) (Fig. 6B). (15) Depressões marginais dos tergos IV, V e VI respectivamente 0, 12: 0,12: 0,06 mm. (16) Bordo posterior do esterno II amplamente bissinuado com um tufo piloso em cada emarginação (Fig. 8B).

Holótipo macho. Brasil, Rio de Janeiro: Rio de Janeiro (Floresta da Tịuca), 8-VI-1966, R.L. Dressler leg. . 444 (USNM). Alótipo fêmea, da mesma localidade, 9-I-1966 (USNM).

Material examinado. Brasıl, Sào Paulo: Dumont, 22-1-1991, (FFCLUSP-RP); quatro machos da Secção Santana, Faz. Santa Carlota, Cajuru, 05-IX1987, Rebêlo leg. 788, 791, 17-X-1987, Rebêlo leg. 826, 827 (FFCL-RP-USP). Vistos numerosos machos do Rio de Janeiro.

Distribuição geográfica. É uma espécie extremamente comum nas matas do Rio de Janeiro como pode constatar-se pelo grande número de indivíduos existentes na Coleção Campos Seabra (MNRJ). Faltam coletas ao longo do litoral Paulista. Tem sido encontrada exclusivamente nos subtropicos da América do Sul. No Brasil, além do Rio de Janeiro, há registro para as matas litorâneas do Espirito Santo, nos campos ruprestes da Serra da Canastra em Minas Gerais e nos cerrados e matas semidecíduas de São Paulo. Existem registros também para o Paraguai e Argentina (Misiones).

Comentários. Esta espécie muito facilmente se distingue das demais pelo coxim anterior da área aveludada oblongo, sem emarginação, pela depressão glandular extremamente longa e pela redução da mancha da área malar à metade anterior. Assemelha-se a imperialis pelo escutelo marcadamente bigiboso e com pontuação esparsa, pelo tuhérculo pré-apical na face inferior das tíbias mesotorácicas. A glossa, em ammectans chega apenas até o ápice do abdômen, enquanto 

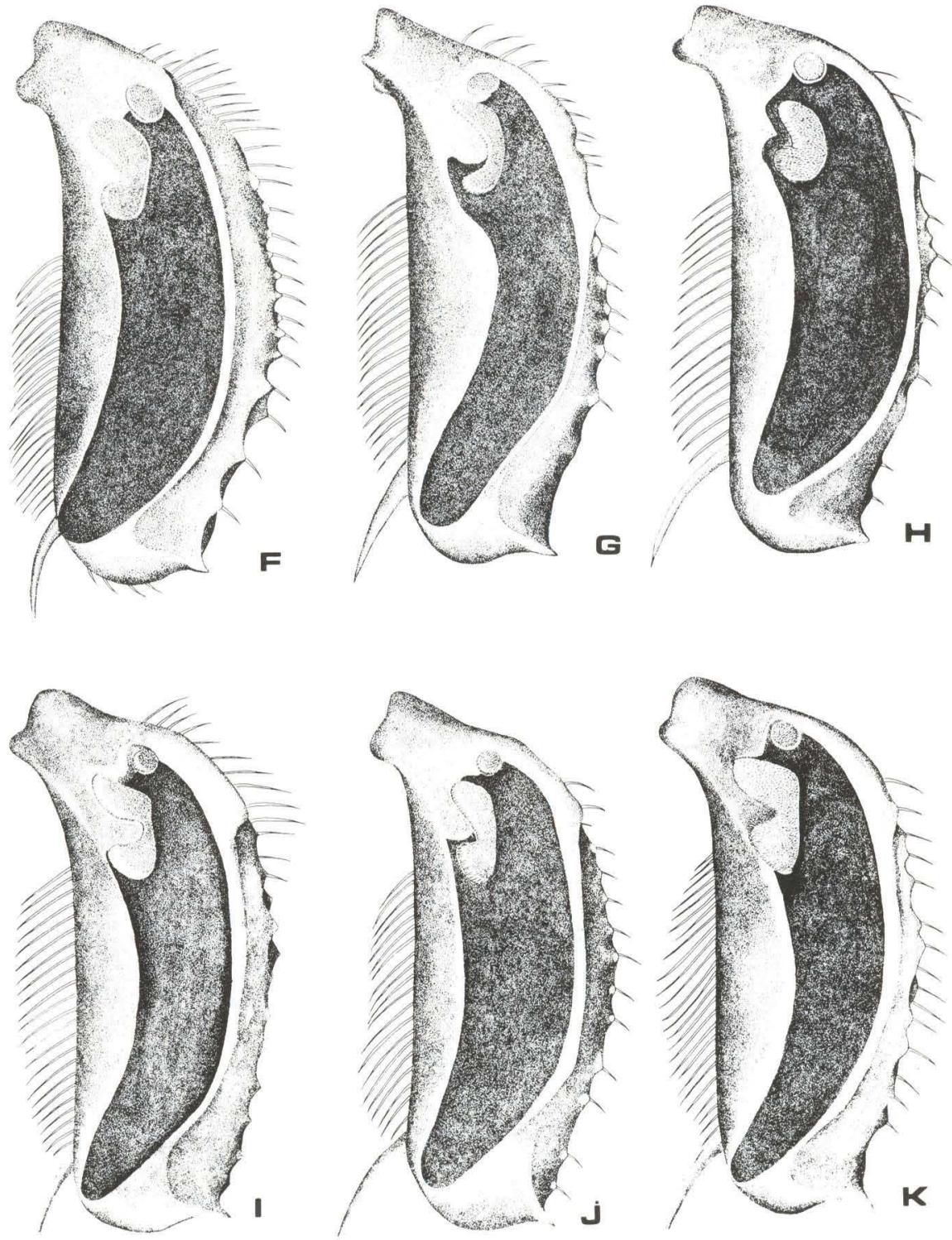

Fig. 5. Vista lateral da tíbia esquerda com destaque para a área aveludada e coxins. (F) Euglossa melanotricha; (G) E. leucotricha; (H) E. cordata; (I) E. securigera; (J) E. fimbriata; (K) E. violaceifrons.

que em imperialis, ultrapassa o comprimento do corpo; em todas as outras espécies incluídas na chave, a glossa é curta, alcançando no máximo, o terceiro externo metasomal. Esta espécie é muito próxima de stellfeldi, diferindo pelo tamanho mais avantajado do corpo, clípeo violáceo nos machos e pelo grande coxim basal; 
ambas combinam aspectos do subgênero Glossura e Euglossa. O nome "annectans", que havia sido dado por MOURE (1965) a esta espécie,refere-se a esta posição intermédia. Os machos são atraídos por cineol, eugenol e vanilina.

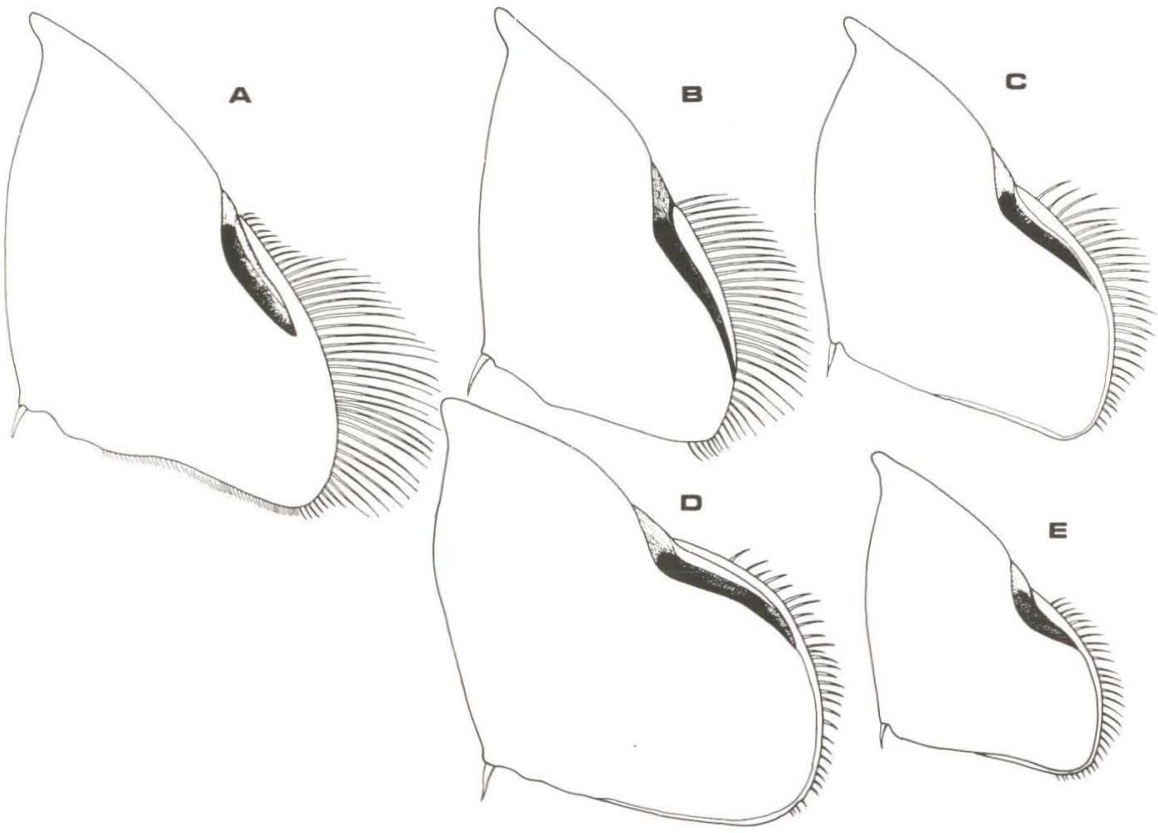

Fig. 6. Vista lateral da metatíbia esquerda com destaque para seu formato, da franja pós-glandular e da depressão posterior: (A) Euglossa imperialis; (B) E. annectens; (C) $E$. truncata; (D) E. pleosticta; (E) E. townsendi.

\section{Euglossa (Euglossa) Latreille, 1802}

Os membros deste subgênero têm a tíbia metatorácica rombóide e o coxim anterior da área aveludada chanfrado (DRESSLER 1978a). Mandíbulas dos machos bidentadas; tufos do segundo esterno pouco desenvolvidos a nulos.

\section{Euglossa (Euglossa) truncata, sp.n.}

Figs $2 \mathrm{C}, 4 \mathrm{C}, 6 \mathrm{C}, 8 \mathrm{~B}$

(1) Tegumento verde. (2) Disco do clípeo violáceo. (3a) Escapo inteiramente preto. (Fig. 2C). (3b) Estrias das áreas paroculares inferiores completas (Fig. 2C). (3c) Áreas malares branco-marfim (Fig. 2C). (4) Pêlos dos tufos metepisternais pretos, (5) das franjas pós-glandulares esparsos e curtos $0,60 \mathrm{~mm}$, (6) dos tufos laterais do tergo $\mathrm{V}$ esparsos e muito curtos, $0,50 \mathrm{~mm}$. (7) Pontuação no mesoscuto densa com pontos de dois tamanhos no disco posterior $(0,038$ $0,04 \mathrm{~mm}),(8)$ no tergo $\mathrm{V}$ densíssima, os pontos alongados ligeiramente pentagonais 

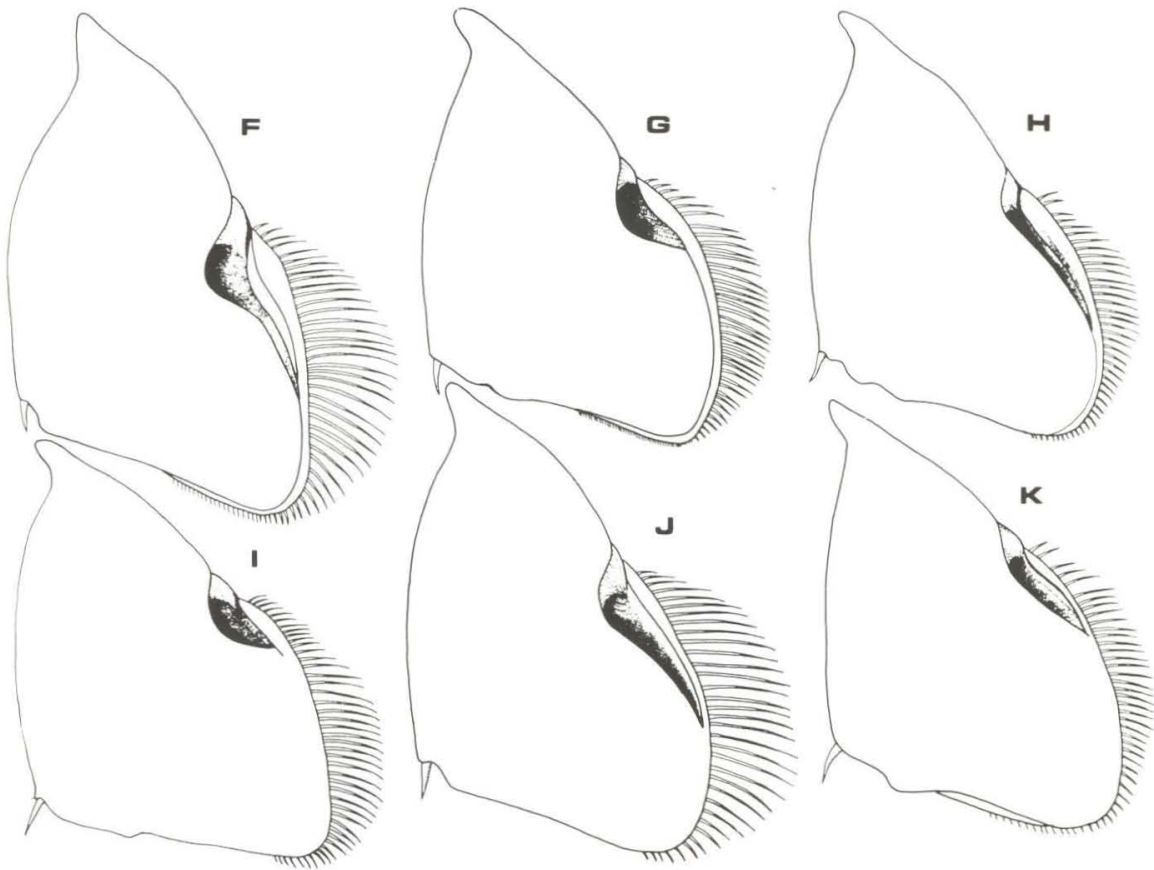

Fig. 7. Vista lateral da metatíbia esquerda com destaque para seu formato, da franja pós-glandular e da depressão posterior. $(\mathrm{F})$ Euglossa melanotricha; $(\mathrm{G})$ E. leucotricha; $(\mathrm{H})$ E. cordata; (I) E. securigera; (J) E. fimbriata; (K) E. violaceifrons.

$(0,08 \mathrm{~mm})$ deixando uma área lisa na linha média longitudinal. (9) Porção póspalpal da gálea até o esterno II. (10) Escutelo convexo com uma leve depressão no terço distal da linha média longitudinal, as vezes, perceptível só em determinado ângulo durante o manuseio sob a lupa; bordo posterior truncado. (11) Área aveludada larga e completa (Fig. 4C). (12) Coxim basal pequeno, oblongo, logo atrás do anterior, este maior, subtriangular, com o bordo anterior levemente obliquo-emarginado (Fig. 4C). (13) Tíbia metatorácica oblongo-rombóide, bastante intumescida, deprimida junto ao bordo distal; canto distal em ângulo obtuso ou rombudo (Fig. 6C); (14) depressão glandular de tamanho médio, um pouco mais longa que um terço do bordo posterior da tíbia (Fig. 6C). (15) Depressão marginal dos tergos mais desenvolvida no I e III, nos demais muito estreita. (16) Esterno II amplamente bissinuado com dois tufos pilosos, um em cada emarginação (Fig. 8B).

Holótipo macho. Brasil, São Paulo: Cajuru (Seç̧ão Santana da Fazenda Santa Carlota), 22-VIII-1987, J.M.M. Rebêlo leg., n ${ }^{\circ} 599$ (FFCL-RP-USP). Mais 10 parátipos da mesma localidade, 05-IX a 17-X-87, 10-I a 27-II-1988 (FFCLRP-USP e DZUP).

Distribuição geográfica. Foi encontrada no nordeste de São Paulo: Cajuru, Luís Antônio, Sertãozinho, Dumont, Ribeirão Preto, Pedregulho, e também em Londrina, Paraná. 
Comentários. Esta espécie se destaca pelo clípeo violáceo e escapo inteiramente preto, os pêlos dos tufos metepisternais predominantemente pretos. $\mathrm{O}$ escutelo nitidamente truncado atrás, o que lhe valeu o nome. Assemelha-se a pleosticta e townsendi pelo coxim anterior subtriangular e pela tíbia metatorácica oblonga, rombóide. Os machos são atraídos por eugenol e cineol.

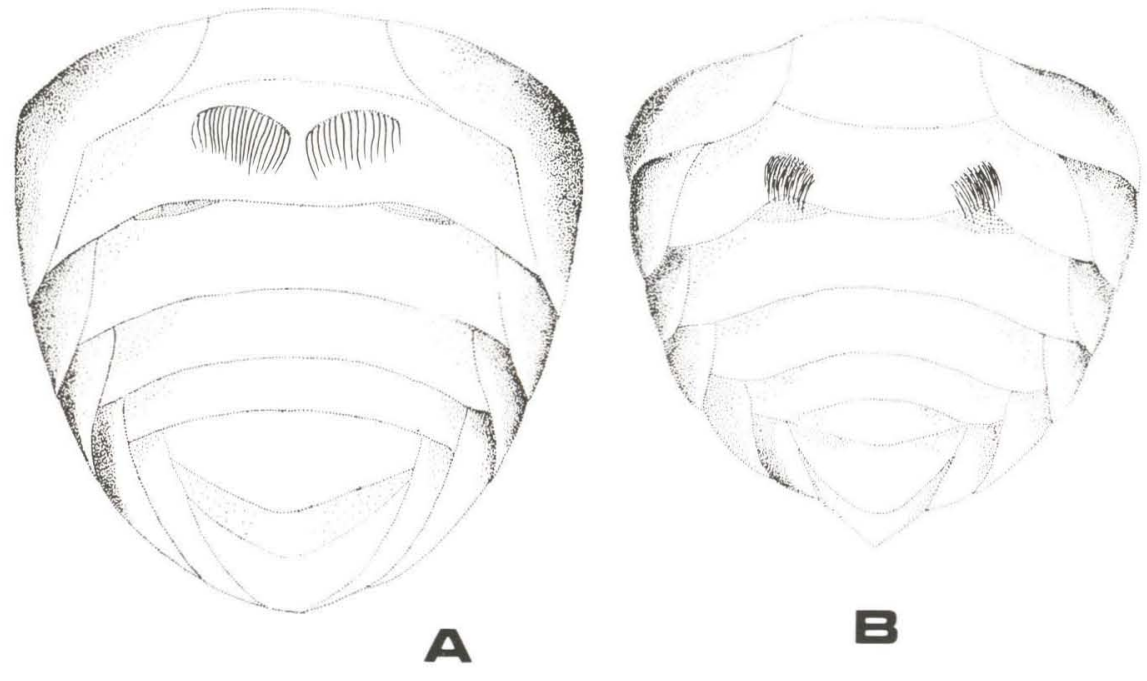

Fig. 8. Lado ventral do abdômen com destaque para os tufos pilosos do segundo esterno em Euglossa imperialis (A) e nas demais espécies (B).

\section{Euglossa (Euglossa) pleosticta Dressler, 1982 \\ Figs $2 \mathrm{D}, 4 \mathrm{D}, 6 \mathrm{D}, 8 \mathrm{~B}$}

Os caracteres 3b, 3c, 9, 11, 13, 14, 16 como em truncata; (1) Tegumento verde-dourado; (2) disco do clípeo azul; (3a) escapo com estria branco-marfim ocupando dois terços da superfície anterior; (4) Pêlos dos tufos metepisternais fulvo-claros, (5) nas franjas pós-glandulares esparsos e curtos 0,46mm (Fig. 6D); (6) nos tufos laterais do tergo $V$ esparsos e muito curtos, $0,30 \mathrm{~mm}$. (7) Pontuação do mesoscuto densa com pontos de dois tamanhos no disco posterior $(0,032-$ $0,04 \mathrm{~mm}) ;(8)$ no tergo $\mathrm{V}$ densíssima, os pontos alongados ligeiramente pentagonais $(0,044-0,06 \mathrm{~mm})$ deixando uma área lisa na linha média longitudinal. (10) Escutelo convexo, com uma leve depressão no terço distal da linha média longitudinal; o bordo posterior arqueado. (12) Coxim basal oblongo e pequeno; o anterior maior, subtriangular e emarginado anteriormente em cunha (Fig. 4D). (15) Depressão marginal dos tergos mais desenvolvida no I e III $(0,08: 0,06 \mathrm{~mm})$, nos demais muito estreita.

Holótipo macho. BRASIL, Espírito Santo: Linhares, 12-XI-1968, R.L. Dressler leg. 1297 (USNM). Alótipo fêmea, mesma localidade, data e coletor 1300 (USNM). 
Material examinado. Brasil, São Paulo: Dumont (Cajuru, na Secção Santana da Fazenda Santa Carlota), três machos, 10-I-1988, J.M.M. Rehêlo leg.; Sertãozinho (Estação Experimental de Zootecnia), três machos, 19-III-1988, 22-I-1991, J.M.M. Rebêloleg.; Dumont (Mata Boa Vista), dois machos, Camillo \& Rebêloleg. (FFCL-RP-USP).

Distribuição geográfica. Freqüente nas matas litorâneas do Espirito Santo, Rio de Janeiro, sudoeste de Minas Gerais e nos cerrados e matas semidecíduas do nordeste de São Paulo.

Comentários. Esta espécie se destaca pela tíbia metatorácica bastante intumescida, rombuda e com intenso brilho dourado. Este caráter associado ao clípeo azul e pêlos do metepisterno exclusivamente fulvo-claros separam-na de truncata e townsendi. O nome específico dado por Moure a esta espécie em 1968, refere-se à pontuação densissima com intervalos careniformes do tergo II. Os exemplares de Dressler foram comparados. Os machos são atraídos por cineol, eugenol e vanilina.

\section{Euglossa (Euglossa) townsendi Cockerell, 1904}

Figs $2 \mathrm{E}, 4 \mathrm{E}, 6 \mathrm{E}, 8 \mathrm{~B}$

Os caracteres 1, 3a, 3b, 3c, 9, 11, 14, 16 como em pleosticta. (2) Disco do clípeo violáceo. (4) Pêlos dos tufos metepisternais fulvo-claros, às vezes com alguns pretos misturados, (5) na franja pós-glandular esparsos e curtos $(0,30$ $0.41 \mathrm{~mm}$ ), (6) nos tufos laterais do tergo $\mathrm{V}$ esparsos e médios até $0,48 \mathrm{~mm}$. (7) Pontos do mesoscuto densos e médios (0.03-0.04mm); (8) no tergo $\mathrm{V}$ densíssimos, alongados e pentagonais $(0,05-0,07 \mathrm{~mm})$ deixando área lisa longitudinal na linha média. (10) Escutelo em arco rebaixado. (12) Coxim basal circular pequeno; o anterior, grande, de contorno subtriangular e levemente emarginado no bordo externo deixando um lobo inferior pequeno (Fig. 4E). (13) Tíbia metatorácica oblongo-rombóide, intumescida no meio e gradualmente deprimida para o ápice obtuso (Fig. 4E). (15) Depressão marginal dos tergos IV, V e VI, mais larga $(0,06 \mathrm{~mm})$.

Lectótipo fêmea (Moure 1957). MÉxico, San Rafael: Vera Cruz, (AMNH, New York). Foi estudado por MOURE (1957) em cuja coleção há exemplares comparados com o tipo.

Material examinado. Brasil, São Paulo: Cajuru (Fazenda Santa Carlota), um macho, ninho NG1, 11-XII-1987; Ribeirão Preto, um macho, ninho LAZ, 05-VI-1991; cinco machos, ninho SZ, 7-9-11-14-19,1, 1991 (FFCL-RP-USP).

Trata-se de uma espécie com enorme distribuição geogrática, descle o México até o Norte da Argentina.

Comentários. Esta espécie pertence, como as duas anteriores, ao grupo purpurea Friese, 1899, pelo coxim anterior subtriangular e tíbia metatorácica oblonga, rombóide. Distingue-se particularmente pelo escutelo bastante longo, sem depressão média, como que inchado e o bordo posterior em arco rebaixado. Assemelha-se a avicula Dressler, 1982, pelo pequeno lobo inferior do coxim 
anterior. Os machos são atraídos por cineol e eugenol. As fêmeas se destacam pelo minúsculo tufo escutelar, colocado quase no bordo posterior.

\section{Euglossa (Euglossa) melanotricha Moure 1967}

Figs $3 F, 5 F, 7 F, 8 B$

Os caracteres 9, 11, 16 como em townsendi. (1) Tegumento verde-azulado a azul intenso; (2) disco do clípeo azul contrastando com suas laterais verde-claras; (3a) escapo inteiramente preto (Fig. 3F); (3b) estrias das áreas paroculares inferiores completas e alargadas embaixo (Fig. 3F); (3c) áreas malares inteiramente branco-marfim (Fig. 3F). (4) Pêlos dos tufos metepisternais pretos, (5) na franja pós-glandular muito longos $(0,80-1,00 \mathrm{~mm})$ (Fig. $7 \mathrm{~F})$; (6) nas franjas laterais do tergo $\mathrm{V}$ densos e longos $(0,70-0,80 \mathrm{~mm})$. (7) Pontos do mesoscuto densíssimos e médios $(0,03-0,05 \mathrm{~mm})$; (8) no tergo $\mathrm{V}$ superficiais, esparsos, irregulares e grandes (até $0,12 \mathrm{~mm}$ ). (10) Escutelo convexo, levemente deprimido ao longo da linha média longitudinal na metade distal; com bordo posterior arqueado. (12) Coxim basal pequeno, circular; o anterior tipicamente reniforme com o lobo superior quase o dobro do inferior (Fig. 5F). (13) Tíbia metatorácica triangular, rombóide, intumescida no meio e deprimida para o bordo distal; com uma protuberância na base do hordo pós-glandular; o ápice sub-agudo (Fig. 7F), (14) a depressão glandular curta, menos de $1 / 3$ do comprimento do bordo posterior da tíbia (Fig. 7F). (15) Depressão marginal estriada e relativamente bem desenvolvida nos tergos IV e V $(0,20: 0,14 \mathrm{~mm})$.

Holótipo macho. Brasil, Mincus Gerais: Araxá, 28-IV-1965, C. Elias leg. , na coleção Moure (DZUP).

Material examinado. Brasil, Sào Paulo: Cajuru (Secção Santana, Fazenda Santa Carlota), três machos, I1-IV/20-XII-1987, No812, 819, J.M.M. Rebêlo leg., 31-III-1988, No 915, J.M.M. Rebêlo leg., Pedregulho (Reserva Ecológica Pedregulho) três machos, 13-27-X/, 22-XII-1990, S. Mateus leg. (FFCL-RPUSP).

Distribuição geográfica. Há registros de ocorrência em diversos hábitats do Brasil: nos cerrados da Bahia, nos campos rupestres de Minas Gerais, nos cerrados e matas semidecíduas de São Paulo, nos cerrados de Goiás e Mato Grosso. O registro mais a oeste é de Santiago, Bolívia.

Comentários. DRESSLER (1978a) equivocadamente coloca esta espécie no grupo purpurea, do qual se afasta pelo formato do coxim anterior e da tíbia metatorácica, típicos do grupo cordata. O último carater e a largura das franjas pós-glandulares aproximam-na um pouco a fimbriata, enquanto a côr do tegumento e a densidade da pontuação lembra leucotricha, descrita a seguir. Entretanto, separa-se facilmente das espécies da região pelo predomínio de pêlos pretos na cabeça tórax e, especialmente, nas franjas das pernas protorácicas, e pela pontuação irregular do tergo V. Os machos são atraídos por cineol e eugenol. 


\section{Euglossa (Euglossa) leucotricha, sp.n. Figs 3G, 5G, 7G, 8B}

Os caracteres 1, 2, 3a, 3c, 4, 9, 16 e 16 como em melanotricha. (3b) Estrias das áreas paroculares inferiores encurtadas inferiormente e bem estreitas (Fig. 3G). (5) Pêlos das franjas pós-glandulares médios $(0,68)$ (Fig. 7G), (6) nas franjas laterais do terg̨o $V$ curtos. (7) Pontuação do mesoscuto densíssima, os pontos médios $(0,04 \mathrm{~mm}),(8)$ no tergo $\mathrm{V}$ grosia $(0,06 \mathrm{~mm})$, regular, mais alongacla para o bordo distal. (10) Escutelo em areo muito rebaixado com os cantos arredondados e a depressão mais evidente no terço posterior. (11) Área aveludada quase completa, mais estreita nos dois terços distais (Fig. 5G). (12) O coxim anterior profundamente sinuado e estreito um pouco mais dilatado nas extremidades (Fig. 5G). (13) Tíbia metatorácica triangular, rombóide, com o canto distal posterior em ângulo subagudo projetado para trás (Fig. 7G). (15) Depressão marginal dos tergos lisa.

Holótipo macho. Brasil, São Paulo: Dumont (Boa Vista), 22-I-1991, Camilo-Macário leg. (FCLRP-USP); Pedregulho e Cajuru, três parátipos, na Coleção Moure (DZUP).

Distribuição geográfica. Brasil, São Paulo: Dumont, Pedregulho e Cajuru.

Comentários. Esta espécie chama a atenção pela cor verde-azulada do tegumento, pela pontuação cerrada no mesoscuto e escutelo e principalmente pelo formato do coxim anterior, em arco estreito, o bordo anterior amplamente aberto. Os dois primeiros caracteres aproximam-na de melanotricha.

\section{Euglossa (Euglossa) cordata (Linnaeus, 1758)}

Figs $3 \mathrm{H}, 5 \mathrm{H}, 7 \mathrm{H}, 8 \mathrm{~B}$

Os caracteres 1, 3a, 3b, 3c, 9, 14, 16 como em pleosticta. (2) Disco do clípeo verde a levemente azulado. (4) Pêlos dos metepisternos fulvo-claros, (5) nas franjas pós-glandulares densos e de tamanho médio $(0,52 \mathrm{~mm})$; (6) nos tufos laterais do tergo V esparsos e curtos $(0,43 \mathrm{~mm})$. (7) Pontuação no mesoscuto densa: no disco posterior densíssima com predomínio de pontos médios $(0,03 \mathrm{~mm})$ sobre os maiores, mais esparsos $(0,04 \mathrm{~mm})$, (8) no tergo $\mathrm{V}$ densíssima, os pontos grossos, regulares $(0,04-0,06 \mathrm{~mm})$, sem área lisa na linha média longitudinal. (10) Escutelo convexo com uma leve depressão nos dois terços distais na linha média; arqueado atrás. (13) Área aveludada larga, estreitada no ápice, encurtada (Fig. 5H). (12) Coxim basal pequeno, quase circular; o anterior maior, a margem externa recortada em ângulo reto, deixando o loho proximal semi-circular, alongado, o distal menor (Fig. 5H). (13) Tíbia metatorácica triangular, rombóide, hastante intumescida no meio, deprimida gradualmente para as extremidades; o canto distal posterior rombudo ou obtuso (Fig. 7H). (15) Depressões marginais dos três primeiros tergos tão largas como 0,06: 0,04: 0,02 mm, nos restantes inconspícuas.

Holótipo fêmea, faltando a cabeça, na Coleção De Geer, sem procedência (NHRM, Stockholm). 
Material examinado. Brasil, São Paulo: Ribeirão Preto (Campus da USP. Setor de Ecologia), um macho, ninho RPI, 19-X-1990; (Reserva de Santa Teresa), um macho, 08-12-1989; Cajuru (Seção Itaoca, Fazenda Santa Carlota), dois machos, II-1991, J.M.M. Rebêlo leg.; Ribeirão Preto (Campus da USP, Setor de Ecologia), sete machos, 14-I-1992 (FFCLRP-USP).

Distribuição geográfica. Segundo Dressler, desde o Panamá até São Paulo, com registro para Colombia, Guianas, Trinidad. e no Brasil desde o Amazonas até São Paulo.

Comentários. Esta espécie foi de difícil interpretação, para a maioria dos autores que a ela se referiram, praticamente com base na curtíssima descrição feita por Linnaeus, e sem um estudo direto do tipo. Este, uma fêmea, conservada no Museu Real de História Natural de Estocolmo, numa das gavetas da Coleção De Geer (Carl) foi por Moure (1958) fotografada e estudada detalhadamente. Falta a cabeça. Foi comparada com exemplares fềmeas do Rio de Janeiro, consideradas como homeótipos. Na Coleção Campos Seabra, agora no Museu Nacional do Rio de Janeiro (MNRJ), existem numerosos exemplares coletados principalmente na Floresta da Tijuca, sendo muito freqüentes os machos em flores de Anthurium. Comparando esses machos com os obtidos de ninhos foi possivel precisar melhor os caracteres de $E$. cordata.

Deve ser destacado o trahalho de Garótalo e colaboradores que conseguiram criar e multiplicar em ninhos artificiais esta espécie, partindo de ninhos obtidos em Ribeirão Preto e Cajuru. Este achado confirma a associação dos sexos e a interpretação de Moure para os machos.

Distingue-se das demais por ter o coxim anterior mais ou menos em forma de " $\mathrm{C}$ ", com o bordo anterior emarginado em ângulo reto e a tíbia metatorácica entre rombuda como em pleosticta e subtriangular como em fimbriata. Separa-se desta última, também pela estrias paroculares completas. Os machos são atraídos por cineol.

\section{Euglossa (Euglossa) securigera Dressler, 1982}

Figs $31,51,71,8 \mathrm{~B}$

Os caracteres 1, 3c, 9 e 16, como em cordata. (2) Disco do clípeo verde-escuro ou verde-azulado, contrastando com suas laterais verde-douradas; (3a) a estria do escapo curta, ocupando um terço da superfície anterior (Fig. 3I); (3b) estreita e curta nas paroculares inferiores (Fig. 3I). (4) Pêlos dos tufos metepisternais fulvo-claros, às vezes misturados com pretos, (5) nas franjas do bordo pós-glandular densos e de tamanho médio até $0,70 \mathrm{~mm}$, (6) nos tufos laterais do tergo $V$ densos e de comprimento médio $(0,52 \mathrm{~mm})$. (7) Pontuação do mesoscuto densa 0,032 e $0,04 \mathrm{~mm}$, (8) densíssima e regular no tergo $V$ com pontos circulares $(0,048-0,05 \mathrm{~mm})$, sem área lisa ao longo da linha média. (10) Escutelo convexo com uma leve depressão ao longo da metade distal da linha média; truncado atrás e os cantos arredondados. (13) Área aveludada completa e progressivamente atenuada para o ápice da tíbia (Fig. 5I). (12) O coxim basal pequeno, circular; o anterior grande, profundamente emarginado, formando dois lobos distintos sub- 
paralelos (Fig. 5I). (13) Tíbia metatorácica triangular, trapezóide, intumescida no meio, gradualmente deprimida para o bordo distal e para o ápice levemente levantado; bordo anterior convexo, curto, um pouco mais de dois terços do posterior também convexo; bordo pós-glandular mais projetado para trás; (Fig. 7I); (14) depressão glandular curta, um pouco menor que um terço do comprimento do bordo posterior da tíbia (Fig. 7I). (15) Depressão marginal dos tergos metasomais inconspícua.

Holótipo macho. Brasil, Expírito Santo: Conceição da Barra, 13-XI-1968, R.L. Dressler leg. 1283 (USNM).

Material examinado. Brasil, São Paulo: Cajuru (Secção Itaoca, Fazenda Santa Carlota), um macho, XII-1990, J.M.M. Rebêlo leg.; Pedregulho (Reserva Ecológica de Pedregulho), sete machos, 23-XII-1989, 06/29-I-1990, 17/31-III1990, 27-X-1990, S. Mateus leg. (FFCLRP-USP).

Distribuição geográfica. Ocorre nos cerrados da Bahia, nas matas do Espirito Santo e no nordeste de São Paulo. Foi encontrada também, em São Luís, Maranhão, na Bolívia e na Venezuela. Exemplares na Coleção Moure, determinados como securigera desde 1966, com que foram comparados os exemplares "tipos" de Dressler.

Comentários. Logo se destaca pelo coxim anterior da área aveludada, profundamente emarginado deixando as extremidades pouco abertas, subpararelas; tíbia metatorácica sem rebordo pré-apical, densamente pontuada os pontos grandes da metade distal concentrados em séries dirigidas para o ápice. Tíbia bastante deprimida, em forma de "machado" o que lhe valeu o nome dado por MourE (1966). Os machos são atraídos por cineol e eugenol

\section{Euglossa (Euglossa) fimbriata, sp.n. \\ Figs $3 \mathrm{~J}, 5 \mathrm{~J}, 7 \mathrm{~J}, 8 \mathrm{~B}$}

Os caracteres 3c, 9, 11 e 16 como em securigera. (1) Tegumento verde; (2) clípeo verde; (3a) estria do escapo curta; (3b) estrias paroculares curtas e estreitas (Fig. 3J). (4) Pêlos dos tufos metepisternais pretos e claros misturados, (5) os da franja pós-glandular até $0,86 \mathrm{~mm}$, e (6) nos tufos laterais do tergo $\mathrm{V}$ até $0,58 \mathrm{~mm}$. (7) Pontuação do mesoscuto $0,04-0,05 \mathrm{~mm}$, (8) no tergo $V$ densa e forte 0,06-0,10mm. (10) Escutelo convexo com o bordo posterior arqueado. (12) Coxim basal arredondado, o anterior emarginado com o lobo proximal maior, alongado e o distal semi-arredondado (Fig. 5J). (13) Tíbia metatorácica triangular rombóide (Fig. 7J), (14) depressão glandular cerca de dois terços comprimento do bordo posterior. (15) Depressão marginal dos tergos estreita.

Holótipo macho. Brasıl, São Paulo: Luis Antônio (Reserva Ecológica Jataí), 18-V-1992; J.M.M. Rebêlo leg.; Cajuru (Secęão Itaoca, Fazenda Santa Carlota), oito parátipos, 3 e 17-X, 19 e 28-XI, 8-XII-1987, J.M.M. Rebêlo leg. (FFCL-RP-USP). Coleção Moure (DZUP).

Distribuição geográfica. Além das localidades acima do Nordeste de São Paulo, há registro também para o Espirito Santo (exemplares coletados por 
Claudionor Elias em 65/66 a que Moure atribuiu este nome).

Comentários. Esta espécie se aproxima de securigera pelo aspecto deprimido da porção distal da tíbia metatorácica. Note-se, porém que em fimbriata o canto distal é mais projetado para trás. Esta espécie é muito característica pela pilosidade predominante branca, pelo coxim anterior emarginado em cunha e, principalmente pela larga fímbria pós-glandular o que lhe valeu o nome. Os machos são atraídos por cineol, eugenol e vanilina.

\section{Euglossa (Euglossa) violaceifrons, sp.n. \\ Figs 3K, 5K, 7K, 8B}

Os caracteres $3 \mathrm{a}, 3 \mathrm{~b}, 3 \mathrm{c}, 9$ e 16 como em cordata. (1) Tegumento verde; (2) disco do clípeo violáceo. (4) Tufos metepisternais com pêlos pretos e esbranquiçados misturados, (5) a franja pós-glandular moderada $0,68 \mathrm{~mm}$ (Fig. 7K) e (6) os pêlos dos tufos laterais do tergo V curtos $0,30 \mathrm{~mm}$. (7) Pontuação do mesoscuto fina $0,03-0,038 \mathrm{~mm}$, (8) no tergo $V$ grossa $0,06-0,08 \mathrm{~mm}$, esparsa e irregular. (10) Escutelo sem depressão média, o contorno posterior em arco. (13) Área aveludada completa e progressivamente estreitada para o ápice da tibia (Fig. 5K); (12) coxim basal arredondado; o anterior estreitamente emarginado formando dois lobos distintos, o superior maior e mais delgado (Fig. 5K). (13) Tíbia metatorácica oblonga rombóide, bastante intumescida (Fig. 7K), (14) a depressão glandular curta, menos de $1 / 3$ do comprimento do bordo posterior da tíbia. (15) Depressão marginal estreita e bem definida nos tergos I-V (0,06: 0,06: 0,04: 0,04: 0,08mm).

Holótipo macho. Brasıl, Sào Paulo: Cajuru (Secção Itaoca, Fazenda Santa Carlota), 21-II-1991, J.M.M. Rebêlo leg. , n 901, Coleção Moure (DZUP).

Distribuição geográfica. Brasil, São Paulo: Cajuru.

Comentários. É muito característica pelo clípeo violáceo, escutelo giboso e sem depressão média (como em townsendi) e pela tíbia metatorácica hastante intumescida com o bordo pós-glandular fortemente convexo. Esta combinação de caracteres mais a pontuação e os desenhos branco-marfim da face lembram pleosticta e townsendi, porém a forma do coxim anterior aproxima-a de fimbriata. O único macho coletado foi atraído por cineol.

\section{REFERÊNCIAS BIBLIOGRÁFICAS}

Dressler, R.L. 1978a. New species of Euglossa from Mexico and Central America. Rev. Biol. Trop. 26 (1): 167-185.

. 1978b. An infrageneric classifiction of Euglossa, with notes on some features of special taxonomic importance (Hymenoptera: Apidae). Rev. Biol. Trop. 26 (1): 187-198.

Kimsey, L.S. \& R.L. Dressler. 1986. Synonymic species list of Euglossini. Pan-Pacific Entomologist 62 (3): 229-236.

Mateus, S.; C.A. Garófalo \& J.M.M. RebÊLO. 1993. Espécies de Euglossini (Hymenoptera, Apidae) do Parque Estadual das Furnas do Bom Jesus, Pedregulho, São Paulo. Res. XIV Congr. Bras. Ent., Piracicaba, p. 252. 
Moure, J.S. 1967. A checklist of the known euglossine bees. Atas Simp. Biota Amazônica, Zool. 5: 395-415.

. The Central American species of Euglossa subgenus Glossura Cockerell, 1917 (Hymenoptera, Apidae). Rev. Biol. Trop. 15 (2): 227-247.

Rebêlo, J.M.M. \& C.A. Garófalo. 1991. Diversidade e sazonalidade de machos de Euglossini (Hymenoptera, Apidae) e preferências por íscas-odores em um fragmento de floresta no sudeste do Brasil. Rev. Bras. Biol. 51 (4): 787-799. 